\title{
Composition of rapeseed cakes and meals manufactured under different technological conditions
}

\author{
M. Wiąz ${ }^{1,3}$, W. Mroczyk ${ }^{2}$, D. Józefiak ${ }^{1}$ and A. Rutkowski ${ }^{1}$ \\ The August Cieszkowski Agricultural University of Poznań, \\ ${ }^{1}$ Department of Animal Nutrition and Feed Management, \\ ${ }^{2}$ Department of Chemistry \\ Wolyńska 33, 60-637 Poznań, Poland
}

\begin{abstract}
The composition of 40 rapeseed meals and 40 rapeseed press cakes produced from rape seed from the 2003 harvest in different production plants in Poland and toasted for 20 or 30 min was determined. Toasting time was found to negatively affect the lysine availability coefficient in both rapeseed meals and cakes. The content of glucosinolates averaged $14.6 \mu \mathrm{M} / \mathrm{g}$ dry matter in rapeseed meals and $17.4 \mu \mathrm{M} / \mathrm{g} \mathrm{DM}$ in rapeseed cakes, both within permitted limits.
\end{abstract}

KEY WORDS: rapeseed, cakes, toasting time, available lysine, glucosinolates

\section{INTRODUCTION}

Processes occurring in the course of de-oiling seeds of oil crop plants are frequently not neutral for the obtained by-products, post-extraction meals and cakes. The high temperature applied, its duration, as well as high pressure, acting singly or in combination, can lead to deterioration of the nutritive value of protein as a result of destruction of exogenous amino acids, primarily lysine (Pastuszewska et al., 1998, 2003). As a consequence of the lower biological value of protein, the value of rape products as protein sources for monogastric animals decreases. However, investigations carried out by Jensen et al. (1994) and Nyström et al. (1996) showed that each technological stage of the industrial process of oil production

\footnotetext{
${ }^{3}$ Corresponding author: e-mail: wiaz@au.poznan.pl
} 
(extraction, toasting or heating) reduced the concentration of glucosinolates, both in solvent meals and press cakes, which improves their feed quality.

\section{MATERIAL AND METHODS}

The investigations were conducted on 40 samples of solvent rapeseed meals obtained from the Oil Plant in Szamotuly and 40 samples of rapeseed cakes obtained from the Oil Plant in Malczewo, produced from batches of commercial double-low rapeseed of unknown varieties from the 2003 harvest. Samples for analyses were collected systematically during the production season of 2003 for 5 consecutive weeks. Once a week, in each of the above-mentioned plants, 4 samples after the shorter (20 $\mathrm{min}$ ) and 4 samples after the longer (30 min) toasting time were collected. The solvent rapeseed meals were obtained by the benzene extraction method at a temperature from 90 to $95^{\circ} \mathrm{C}$ at two toasting times: 20 and $30 \mathrm{~min}$ and 200 atmosphere pressure. The rapeseed cakes were obtained by the pressing method at a temperature from 100 to $105^{\circ} \mathrm{C}$, toasting time of 20 and 30 min and 150 atmosphere pressure.

Crude nutrients were determined according to AOAC (1990), glucosinolate content on a Hewlett Packard gas chromatograph. Total lysine was determined on a T 339 AminoAcid Analyser. Available lysine was determined using the Carpenter (1973) method. Data were analysed by one-way analysis of variance with the use of Statgraphics Plus ver. 6 software.

\section{RESULTS AND DISCUSSION}

Statistically significant differences were found $(\mathrm{P}<0.05)$ in the content of total lysine (Table 1) in the examined rapeseed meals sampled after 20 or $30 \mathrm{~min}$ of toasting, whereas the levels of available lysine were comparable. Similar values were reported by Jensen et al. (1995) and Pastuszewska et al. (1998). However, the lysine availability coefficients were lower $(\mathrm{P}<0.05)$ after the longer toasting time. This was caused mainly by the greater quantities of total lysine, because the level of available lysine was not affected by toasting time. The higher lysine availability coefficient in rapeseed meals toasted for shorter time is in agreement with other studies (Pastuszewska et al., 2003), while the apparently greater content of total lysine in meals toasted for 30 rather than $20 \mathrm{~min}$, found in the present study, is difficult to explain. The content of glucosinolates in solvent meals did not depend on toasting time. The crude protein, crude fat and crude fibre contents were similar in the examined samples.

The levels of total and available lysine in the examined rapeseed cakes sampled after 20 or 30 min of toasting were similar as in solvent meals (Table 1) 
and available lysine coefficients were higher following the shorter toasting time. Similar observations concerning the impact of the length of toasting time on lysine availability in rapeseed products were also made by Nyström et al. (1996) and Pastuszewska et al. (1998). The glucosinolate contents were lower in rapeseed meals than in rapeseed cakes; in the latter it was higher $(\mathrm{P}<0.05)$ when sampled after the longer toasting time indicating that the level of these compounds in the rape seeds used in the production process was variable. However, the average content of glucosinolates in 80 investigated samples was within limits for " 00 " rapeseed, indicating that rapeseed products from both Oil Plants may be safely used in feeding animals.

Table 1. Composition of commercial rapeseed meals and cakes

\begin{tabular}{|c|c|c|c|c|c|c|c|c|}
\hline $\begin{array}{l}\text { Toasting } \\
\text { time }\end{array}$ & $\mathrm{n}$ & $\begin{array}{c}\mathrm{CP} \\
\% \mathrm{DM}\end{array}$ & $\begin{array}{c}\mathrm{TL} \\
\mathrm{g} / 16 \mathrm{~g} \mathrm{~N}\end{array}$ & $\underset{\mathrm{g} / 16 \mathrm{~g} \mathrm{~N}}{\mathrm{AL}}$ & $\mathrm{AL} / \mathrm{TL}$ & $\begin{array}{c}\text { CFat } \\
\% \text { DM }\end{array}$ & $\begin{array}{c}\text { CF } \\
\% \mathrm{DM}\end{array}$ & $\underset{\mu \mathrm{mol} / \mathrm{g} D M}{\mathrm{G}}$ \\
\hline \multicolumn{9}{|c|}{ Rapeseed meals } \\
\hline $20 \mathrm{~min}$ & 20 & $39.4^{\mathrm{a}}$ & $5.5^{\mathrm{a}}$ & 4.8 & $87.5^{\mathrm{a}}$ & 5.0 & 16.2 & 14.7 \\
\hline $30 \mathrm{~min}$ & 20 & $38.8^{\mathrm{b}}$ & $6.3^{\mathrm{b}}$ & 4.8 & $77.5^{\mathrm{b}}$ & 5.3 & 16.1 & 14.5 \\
\hline SEM & & 0.14 & 0.08 & 0.02 & 1.4 & 0.14 & 0.07 & 0.51 \\
\hline \multicolumn{9}{|c|}{ Rapeseed cakes } \\
\hline $20 \mathrm{~min}$ & 20 & $35.9^{\mathrm{a}}$ & $5.6^{\mathrm{a}}$ & 4.9 & $88.6^{\mathrm{a}}$ & $12.3^{\mathrm{a}}$ & 14.3 & $16.5^{\mathrm{a}}$ \\
\hline $30 \mathrm{~min}$ & 20 & $36.8^{\mathrm{b}}$ & $6.2^{\mathrm{b}}$ & 4.8 & $78.9^{\mathrm{b}}$ & $11.2^{\mathrm{b}}$ & 14.4 & $18.3^{\mathrm{b}}$ \\
\hline SEM & & 0.15 & 0.12 & 0.04 & 1.87 & 0.18 & 0.07 & 0.51 \\
\hline
\end{tabular}

\section{CONCLUSIONS}

It seems that industrially produced rapeseed meals and cakes in 2003 were of good nutritional quality.

\section{REFERENCES}

AOAC, 1990. Association of Official Analytical Chemists, Official Methods of Analysis. $15^{\text {th }}$ Edition. Washington, DC

Carpenter K.J., 1973. Damage to lysine in food processing: Its measurement and its significance. Nutr. Abstr. Rev. 43, 423-451

Jensen S.K., Yong-Gang L., Eggum B.O., 1995. The effect of heat treatment on glucosinolates and nutritional value of rapeseed meal in rats. Anim. Feed Sci. Tech. 53, 17-28

Nyström R., Pastuszewska B., Buraczewska L., Tulisalo U., Ochtabińska A., 1996. Effects of pressing technology of oil separation and heat treatment on the protein value of lowglucosinolate rapeseed cake for non-ruminants. J. Anim. Feed Sci. 5, 235-248 
Pastuszewska B., Buraczewska L., Ochtabińska A., Buraczewski S., 1998. Protein solubility as an indicator of overheating rapeseed oilmeal and cake. J. Anim. Feed Sci. 7, 73-82

Pastuszewska B., Jabłecki G., Buraczewska L., Dakowski P., Taciak M., Matyjek R., Ochtabińska A., 2003. The protein value of differently processed rapeseed solvent meal and cake assessed by in vitro methods and in tests with rats. Anim. Feed Sci. Tech. 106, 175-188

\section{STRESZCZENIE}

\section{Skład śrut i wytłoków rzepakowych otrzymywanych w różnych warunkach technologicznych}

Przedmiotem badań było 40 prób poekstrakcyjnych śrut rzepakowych pochodzących z Zakładów Tłuszczowych w Szamotułach oraz 40 prób wytłoków rzepakowych pochodzących z Zakładu Petroestry SA w Malczewie. Nasiona pochodziły ze zbiorów 2003 roku. Wytłoki rzepakowe zawierały mniej białka ogólnego, a więcej thuszczu surowego i glukozynolanów w porównaniu ze śrutami rzepakowymi. Stwierdzono statystycznie istotny wpływ dłuższego czasu tostowania na obniżenie stopnia dostępności lizyny zarówno w śrutach poekstrakcyjnych jak i wytłokach. Zawartość glukozynolanów wynosiła średnio $14,6 \mu \mathrm{M} / \mathrm{g}$ s. m. w śrutach i 17,4 $\mu \mathrm{M} / \mathrm{g} \mathrm{s}$. m. w wytłokach, co mieściło się w dopuszczalnych granicach. 